the legs, the thighs, the buttocks, the arms, and the forearms. Some of the patches measured one or two inches in diameter. On the 14th there were painful swelling of the left knee-joint and tenderness of all the bones; a purpuric eruption had also commenced on the face. The boy's temperature on the 13th and 14th was normal. I prescribed a mixture containing 24 minims of suprarenalin (Armour), 20 minims of liquor rosæ dulcis, and water to make up one and a half ounces ; one drachm to be taken every four hours. I also ordered the knee to be wrapped in cotton-wool and bandaged. Those purpuric patches which had faded left a brown stain behind. On the 15th the swelling of the knee was better and the celema of the prepuce was gone. There was no further eruption on the extremities but some fresh spots had come out on the face. The child was sitting up and appeared to be much better; his bones were also less tender. On the 16 th all swelling in the knee was gone; the patient continued to take the suprarenalin. On the 20th nearly all the purpuroid patches on the face were gone, leaving brown stains, and the boy was much better.

The case illustrates the following points: (1) combination of wheals and purpura, a combination which is diagnostic if not pathognomonic; (2) moderate pyrexia at the commencement of the illness; (3) swelling of the knee and prepuce; and (4) rapid beneficial action of suprarenalin.

Dover.

\section{A CASE OF CEREBRO-SPINAL MENINGITIS.}

By John M. Bennion, M.B., B.C. Cantab.

IN The LanceT of June 30th, p. 1815, I read with great interest an article by Dr. William Wright and Dr. William Archibald on Epidemic Cerebro-spinal Meningitis and it has induced me to send you the notes of the following case.

The patient, who was a girl, aged six years, was taken ill on June 23rd last with severe headache and the "cold shivers." On the 24th she vomited several times, the mother stativg that the child could keep nothing down. On the 25th, when I saw her for the first time, she was unconscious and delirious, the pupils were large, there was a patch of herpes on the lower lip, and the head was retracted. The temperature was $101 \cdot 2^{\circ} \mathrm{F}$. and the pulse-rate was 80 . The knee-jerks on both sides were exaggerated and Kernig's sign was present. Nothing abnormal was observed in the chest. The girl was much worse on the morning of the $26 \mathrm{th}$, the temperature being $102 \cdot 6^{\circ}$ and the pulse-rate 120 ; the respirations were 48 per minute and were noisy owing to mucus in the throat. A squint was noted: The retraction of the head was more marked. There were constant convulsions which involved the face and all four limbs. It was obvious that the child could not live long and she died early on the morning of the 27th. No lumbar puncture was performed and unfortunately a post-mortem examination was not allowed.

At first sight I thought that the case was one of tuberculous meningitis but the sudcen onset, the labial herpes, and the abrupt termination, I think, justify the diagnosis of cerebro-spinal meningitis. Up to the present no other member of the family has been attacked.

St. Mary Cray, Kent.

\section{A CASE OF ABSENCE OF THE UTERUS.}

By Aluce Maud Sorabjr, M.B., B.S. Lond.

THE patient, who was a Hindoo, aged 19 years, came to me complaining of never having menstruated. She was well-built and well-developed, in fact rather broader and stronger than other girls of her class and age. In appearance there was nothing abnormal about her face or body. She had no hair about the face except the faintest trace on her upper lip. The breasts were well developed. The labia majora were very small and tightly stretched from the anterior to the posterior end; there were no folds representing the labia minora; the clitoris was hypertrophied. On making a vaginal examination the vagina was found to be quite small, only one and a half inches deep at most. No uterus was found. In the posterior wall of the vagina the mucous membrane was at one spot slightly puckered round a central point. She was married. She complained of a "fulness" in the head and the lower part of the abdomen which recurred every four weeks.

Bahawalpur, Punjab, India.

\section{8. \\ or}

\section{HOSPITAL PRAOTIOE BRITISH AND FOREIGN.}

Nuila autem est alia pro certo noscendi via, nisi quamplurimas ot morborum et dissectionum historias, tum aliorum tum proprias collectas habere, et inter se comparare.-MoRGAGNI De Sed. et Caus. Morb., lib. iv., Proœmium.

\section{ROYAL WATERLOO HOSPITAL FOR CHILDREN AND WOMEN.}

A CASE OF APPENDIX ABSCESS WITH AN UNUSUAL COMPLICATION.

(Under the care of Mr. Russeld J. Howard.)

THE patient, a female, aged 17 years, was admitted to the Royal Waterloo Hospital on Feb. 7th, 19C6, complaining of abdominal pain and vomiting. She gave the following history. Whilst dressing on the afternoon of Jan. 24th she was suddenly seized with pain in the right lower abdomen and vomited. She went to bed and was kept on milk and beef-tea but had no medical attendance. Four days after the onset, the symptoms being relieved, she was sent to her own home. There she was confined to bed for most of the day but got up in the afternoon and went to see her medical adviser who prescribed treatment. As the vomiting continued, on Feb. 7th she went to the hospital by omnibus and tram from Wimbledon. During her illness she had taken nothing but milk and beef-tea as she had vomited every day. During the first week the bowels had not been opened but after taking medicine the patient had had diarrhœa.

On admission she complained of pain in the right iliac fossa and a lump which her mother had discovered, nausea, and diarrhoa. She showed the abdominal facies; her tongue was coated and dry. The temperature was $100^{\circ} \mathrm{F}$., the pulse was 116 , and the respirations were 34 . On abdominal examination there was an obvious swelling in the appendix area both to sight and touch. This swelling was resonant on percussion and was situated rather bigher and more internally than the usual appendix abscess. Abdominal respiration was slight and there was marked muscular rigidity of the abdominal walls. Rectal examination made under an anæsthetic revealed nothing abnormal in the pelvis. The diagnosis made was retrocæcal appendix abscess.

Operation was performed six hours after admission. An incision was made over the most prominent part of the swelling and on opening the peritoneal cavity the cæcum came into view and there was an entire absence of adhesions in front. The general peritoneal cavity was shut off with gauze and a slight search revealed an abscess situated in the angle between the ileum and the cæcum, which contained about two ounces of foul-smelling pus. The cavity passed in an upward direction behind the ileum and the crecum. The appendix was not seen and no concretion was found. The abscess cavity and the pouch of Douglas were drained with indiarubber tubes and the wound was partially united with sutures. After the operation the pulse was 115 , the temperature was $101^{\circ}$, and the respirations were 35 .

Progress.-On Feb. 8th the pulse was 112, the respirations were 37 , and the temperature was $98^{\circ}$. Pus was passing out of the abscess cavity but none from Douglas's pouch. There was some abdominal pain but no distension. Incontinence of urine and fæces was present. On the 9th the pulse was 130 , the respirations were 45 , and the temperature was $99^{\circ}$. There was no general abdominal pain or distension but some vomiting was present. Offensive pus came from both tubes. On the 10th there were some abdominal distension and slight vomiting. The general condition had improved. The pulse was 120 , the respirations were 25 , and the temperature was $99 \cdot 6^{\circ}$. On the 12th there were still abdominal distension and slight vomiting bat food was taken well. The tongue was moist. The pulse was 130 , the respirations were 35 , and the temperature was $99^{\circ}$. A turpentine enema was administered which gave relief. At 10 P.M. on the 12 th there was considerable hæmorrhage from the wound which soaked the dressing and filled both tubes with blood clot. When the wound was examined the bleeding had stopped; the tubes 